\title{
ENVIRONMENTAL AND PRACTICAL ASPECTS OF THE USE OF PEAT FOR AGRICULTURE AND ENERGY AIMS
}

\author{
Alina Kowalczyk-Juśko', Joanna Onuch ${ }^{1}$, Bogdan Kościk², Piotr Skowron ${ }^{3}$, \\ Monika Chołody ${ }^{4}$, Andrzej Kosidło ${ }^{5}$, Janusz Rawski ${ }^{6}$
}

1 Faculty of Production Engineering, University of Life Sciences in Lublin, Leszczyńskiego 7, 20-069 Lublin, Poland, e-mail: alina.jusko@up.lublin.pl

2 Pope John Paul II State School of Higher Education in Biała Podlaska, Sidorska 95/97, 21-500 Biała Podlaska, Poland, e-mail: bogdan.koscik48@gmail.com

${ }^{3}$ Faculty of Agrobioengineering, University of Life Sciences in Lublin, Akademicka 15, 20-950 Lublin, Poland, e-mail: piotr.skowron@up.lublin.pl

${ }^{4}$ ART-BRUK Monika Chołody, Wojciechowska 5a, 20-601 Lublin, Poland, e-mail: monikacholody@wp.pl

${ }^{5}$ Biuro Konstrukcyjne A.K. S.C, Jeziorowa 32, 66-218 Lubrza, Poland, e-mail: biuro@akbiurokonstrukcyjne.pl

${ }^{6}$ EKO HARPOON - Organizacja Odzysku S.A., Kardynała Wyszyńskiego 10, Cząstków Mazowiecki, 05-152 Czosnów, Poland, e-mail: biuro@ekoharpoon-organizacjaodzysku.pl

Received: 2016.08.03

Accepted: 2016.09.01

Published: 2016.09.30

\begin{abstract}
The aim of this study was to evaluate physical and energetic parameters of peat. Utility of the peat in horticulture and power generation were also estimated. Peat was mined from the Klejniki deposit, (Hajnówka municipality, Podlaskie province) in the north-eastern part of Poland. It was found that peat can be used for power generation, in the air-dry moisture condition. Peat parameters are similar to lignite. It can also be suitable for the production of horticultural substrates and incorporated into soil as a component for improving physical and chemical properties. The examined peat fulfills the requirements of for agricultural applications.
\end{abstract}

Keywords: peat, physical properties, energy value, power generation, improving soil quality

\section{INTRODUCTION}

Peat is a substance which is the effect of incomplete decomposition of plant debris found in some plant communities under long-term or permanent excessive waterlogging.

Properties of peat depend on the botanical composition of plant communities forming peat bogs, as well as on water and thermal conditions under which the plant remains decomposed [Ilnicki 2002]. There are 50 thousand peat bogs in Poland (natural and dehydrated) larger than 1 ha, covering a total of around 1.3 million ha, which represents $4 \%$ of the country's area. Among these bogs, the dominant type is low peatland, which constitutes $92 \%$ of the area of all bogs. The remaining part is made up of deep (5\%) and transitional peatlands (3\%) [Dembek et al. 2000, Ilnicki 2002].

Peatland areas serve many important functions in the natural environment: as wetlands, they are natural water reservoirs and a habitat of rare and protected plant and animal species often facing extinction [Brandyk et al. 2008]. Current$1 y$, about $15-20 \%$ of peat bogs are utilized agriculturally, with varying intensity. For example, in Holland this number is as high as $85 \%$, while in Finland it is $2 \%$ [Oleszczuk et al. 2008].

Properties of peat depend on the floristic composition of peat-forming plant communities and on water and temperature (climatic) conditions. Peat is saturated with mineral substances in varying degrees. The most common substance is sand, and precipitated iron compounds can be 
found sometimes, while phosphorus compound are quite rare. Peat deposits often have high spatial variability of physical and mechanical properties. Changes in these properties over time are caused by different biological and chemical processes. As a result of successive events taking place during the covering of older deposits by the younger, such as pressure of upper deposit layers, temperature rise, and lack of oxygen, after millions of years, peat turns into lignite and then into coal.

Peat is used in horticulture as a component of garden plant substrates, in agriculture for the production of so-called garden soil and as an organic fertilizer, and in balneology as a material for baths and wraps. The use of peat for agriculture and horticulture is determined by the following quality parameters: the degree of decomposition, ash content, $\mathrm{pH}$, the presence of carbonates, the density of the solid phase, bulk density, and porosity. In addition to the use in agricultural production, peat was a traditional fuel material. Currently, its annual use for heating purposes amounts to approx. 17 million $\mathrm{Mg}$ and on an industrial scale is limited to Finland, Belarus, Ireland and Sweden, while in other European it is used in small quantities [World... 2013].

\section{MATERIALS AND METHODS}

The aim of the study was to evaluate the parameters of peat mined from a deposit located in the north-eastern part of Poland, in terms of its suitability for use in horticulture and as energy source.

The analyzed peat came from the Klejniki deposit, (Hajnówka municipality, Podlaskie province). The samples were collected in the spring of 2013 at a depth of $10-40 \mathrm{~cm}$. For evaluation of physical properties, samples with pre- served natural structure were collected. Laboratory tests included:

- the degree of decomposition - an organoleptic method based on the degree of decomposition by Okruszko [1991] (R1 - peats poorly decomposed, fibrous, R2 - peats of average decomposition, mosaic, R3 - peat highly decomposed, amorphous or lumpamorphous), using a von Post scale (from $\mathrm{H} 1$ - undecomposed peat to H10 - peat completely decomposed);

- ash content - determined by burning previously dried peat samples for 4 hours at $550{ }^{\circ} \mathrm{C}$ in a muffle furnace;

- the content of organic substances - calculated as the loss after burning previously dried peat samples for 4 hours at $550{ }^{\circ} \mathrm{C}$ in a muffle furnace;

- $\mathrm{pH}$ in $\mathrm{H}_{2} \mathrm{O}_{\text {dest. }}$ And in $1 \mathrm{~mol} \cdot \mathrm{dm}^{-3} \mathrm{KCl}$ potentiometrically (soil-solution ratio of 1: 2.5);

- the presence of carbonates - Scheibler method;

- density of solids - the pycnometric method;

- bulk density - after drying the samples with a constant structure placed in Kopecki cylinders at $105^{\circ} \mathrm{C}$;

- porosity - calculated as the relationship between density and the density of the solid phase;

- water capacity - the dryer-weight method.

The second part of the study aimed at evaluating the usefulness of peat deposits from the tested site for energy purposes in thermochemical processes. The analysis of parameters which are important from the energetic point of view was carried out in an accredited Energa Cogeneration laboratory in Elbląg. The sample delivered for testing was subjected to analysis in four states: operational, analytical (air-dry), dry and dry ash-free, using the methods listed in Table 1. The expanded uncertainty was determined for $\mathrm{P}$ $=0.95$ and $\mathrm{k}=2$.

Table 1. Laboratory methods for testing peat

\begin{tabular}{|l|c|c|}
\hline \multicolumn{1}{|c|}{ Parameter } & Standard number & Expanded uncertainty \pm U \\
\hline Total moisture & Q/LP/05/A:2011 pkt 7.2 & 2.62 \\
\hline Ash content & Q/LP/06/A:2011 & 0.82 \\
\hline Gross calorific value and calculation of net calorific value & Q/LP/12/A:2011 & 236 \\
\hline Total sulphur & Q/LP/08/A:2011 & 0.02 \\
\hline Chlorine content & PB 08 wyd. 02 z dn. 10.08.2012 & 0.02 \\
\hline Carbon content & IS 10 wyd. 04 z dn. 10.08.2012 & 0.7 \\
\hline
\end{tabular}




\section{RESULTS}

The test peat contained a large amount of highly distributed plant debris of amorphous structure forming humus. Owing to the high content of humus, it was malleable when moist. Determining dry strength showed high strength. Based on the division of organic material, the sample was specified as amorphous with visible plant remnants, the degree of decomposition - average decomposition (H6), mosaic peat structure with a high proportion of amorphous structure (R2).

Content of minerals, expressed as ash content in the sample was characteristic of low peats. In the studied peat, average ash content was measured to be $11.8 \%$ (Table 2). According to Szymanowski, [1993] for the, ash content stays in the range of $10.8-13.7 \%$. For the upper layers of low, mossy peat bogs, ash content is lower, in the range of $8.4-11.8 \%$.

Based on the peat types classification [Okruszko 1991], the tested sample has been found to be slightly acidic. There was no presence of carbonates in the sample. Density of the examined peat equalled $1510 \mathrm{~kg} \cdot \mathrm{m}^{-3}$ and was characteristic of the density of the solid phase of peat soils'. With the increase in the degree of decomposition of peat, a rise of this feature's value can be observed. The bulk density of the examined peat was $160 \mathrm{~kg} \cdot \mathrm{m}^{-3}$. This value is characteristic of significantly decomposed low peats. The porosity of the peat reached an average value of $0.894 \mathrm{~m}^{3} \cdot \mathrm{m}^{-3}$ (Table 2). The porosity of low peat ranges from $0.928 \mathrm{~m}^{3} \cdot \mathrm{m}^{-3}$ for poorly decomposed mossy peats, through $0.911 \mathrm{~m}^{3} \cdot \mathrm{m}^{-3}$ for the averagely decomposed alder peats, to $0.893 \mathrm{~m}^{3} \cdot \mathrm{m}^{-3}$ for amorphous alder peats [Ilnicki 2002]. For deep peatlands, the porosity values are higher overall, while for mucks they are lower.

A typical state of peat moisture is full water capacity, which, in the case of the sample, ranged from 85 to $87 \%$. This value is characteristic of significantly decomposed peats. These peats exhibit lower total water capacity than poorly decomposed peats, whose full water capacity can reach $93-95 \%$.

From the energetic point of view, a significant limitation for the use of peat is its high moisture content and the necessity to undergo drying before using it as energy source. Air-dry humidity of $17 \%$ allows for the use of peat as a fuel in most heating devices in its various forms: briquettes or pellets (after pre-treatment), in an unprocessed form or after grinding in fluidized-bed boilers. One negative aspect found in the study is a relatively high ash and mineral content. It results from the sedimentation of particles contained in the flowing water, movement of soil particles caused by wind, or is the result of agronomic and drainage works. This parameter can be a limitation for power generation. In the case of burning peat only, remaining ash can be used as fertilizer, but in the case of burning peat together with coal, it will substantially influence the amount of ash generated in the process.

The energy value of solid fuels depends largely on the content of carbon. In the tested sample, its content was marked at $43.6 \%$ in analytical state and at $52.5 \%$ in dry state (Table 3). Main energy parameters: combustion heat and calorific value, determined in analytical and dry states were found to be comparable to the energy value

Table 2. The peat properties - mean values

\begin{tabular}{|c|c|c|}
\hline Feature & Unit & Value \\
\hline Degree of decomposition & $\mathrm{H}$ & $\mathrm{H} 6$ \\
\hline Colour & $\begin{array}{l}\text { wet condition } \\
\text { dry condition }\end{array}$ & $\begin{array}{c}\text { dark brown to pitch-black } \\
\text { brown }\end{array}$ \\
\hline Content of organic substances & $\%$ & 88.2 \\
\hline Ash content & $\%$ & 11.8 \\
\hline \multirow{2}{*}{$\mathrm{pH}$} & $\mathrm{pH}$ in $1 \mathrm{M} \mathrm{KCl}$ & 5.6 \\
\hline & $\mathrm{pH}$ in $\mathrm{H}_{2} \mathrm{O}_{\text {dist. }}$ & 6.1 \\
\hline Presence of carbonates & $\%$ & 0.0 \\
\hline Density of solids & $\mathrm{g} \cdot \mathrm{cm}^{-3}$ & 1.51 \\
\hline Bulk density & $\mathrm{g} \cdot \mathrm{cm}^{-3}$ & 0.16 \\
\hline Porosity & $\%$ & 89.4 \\
\hline Water capacity & $\%$ & 85.6 \\
\hline
\end{tabular}


Table 3. The peat parameters important for energy purposes

\begin{tabular}{|c|c|c|c|c|c|c|}
\hline \multirow{2}{*}{ Parameter } & \multirow{2}{*}{ Symbol } & \multirow{2}{*}{ Unit } & \multicolumn{4}{|l|}{ Condition } \\
\hline & & & operational & analytical & dry & $\begin{array}{l}\text { dry and } \\
\text { ash-free }\end{array}$ \\
\hline Total moisture & $\mathrm{W}_{\mathrm{c}}$ & $\%$ & 87.4 & 17.0 & - & - \\
\hline Ash & $A$ & $\%$ & 1.3 & 8.8 & 10.6 & - \\
\hline Burnt matter & - & $\%$ & 11.2 & 74.1 & 89.4 & - \\
\hline Gross calorific value & $Q_{s}$ & $\mathrm{~kJ} \cdot \mathrm{kg}^{-1}$ & 2651 & 17493 & 21082 & 23595 \\
\hline Net calorific value & $Q_{i}$ & $\mathrm{~kJ} \cdot \mathrm{kg}^{-1}$ & 363 & 16066 & 19863 & 22230 \\
\hline Total sulphur & $S_{t}$ & $\%$ & 0.08 & 0.56 & 0.67 & 0.75 \\
\hline Chlorine & $\mathrm{Cl}$ & $\%$ & 0.01 & 0.04 & 0.05 & 0.05 \\
\hline Carbon & C & $\%$ & 6.6 & 43.6 & 52.5 & 58.8 \\
\hline
\end{tabular}

of lower quality coal. Also, the content of corrosive elements, sulfur and chlorine, was similar to coal energy and at the same time, higher than in most biomass fuels [Tumuluru 2011]. The use of peat as energy is currently limited in Poland due to legal restrictions.

\section{DISCUSSION}

Peat can be used in the production of substrates and incorporated into the soil as a component improving its physical properties. The use of peat as organic fertilizer controls the density and porosity of the substrate, as well as the waterair relations and the structure of the mineral soil [Ilnicki 2002]. The tested peat from Klejniki deposit met the requirements of $\mathrm{PN}-70-\mathrm{G}-98011$ industry standard, which defines the quality of peat for agricultural uses. The quality requirements of raw material contained in the standard include the type of peat (low or transitional), the degree of decomposition - not less than $20 \%$, ash content - not more than $25 \%$, and $\mathrm{pH}$ - not less than 5 .

Peat can be used in agriculture and horticulture as a peat-mineral mixture element, i.e. a mixture of peat and mineral fertilizers and micronutrients. The results of the research by Kwiatkowska-Malina [2011] confirm the possibility of using low peat as a component of fertilizer blends such as Rekulter, which is a mixture of waste coal and low peat.

Introduction of peat into soil contributes to the increase of organic carbon content. Apart from this, peat also reduces the absorption of heavy metals by plants [Wróbel, SienkiewiczCholewa 2009]. The protective properties of peat result from its high sorption capabilities. Sorption in the peat is considered to be an exchangeable sorption. Only neutral and alkaline peats may be characterized by chemical sorption. With the increase of the degree of decomposition of low peat, its sorptive capacity increases as well. Written sources indicate that low peats are characterized by sorptive capacity of $150-240 \mathrm{mmol} \cdot \mathrm{kg}^{-1}$ s.m. [Ilnicki 2002].

Peats suitable for horticultural purposes are those whose water content is below $70 \%$, of ash content of not more than $15 \%$ and are less decomposed. The quality requirements of horticultural class I peat define an even lower permissible ash content level of maximum of $7 \%$. That is why in container-based cultivation and when used as a homogenous substrate in controlled gardening, less decomposed deep peats are usually used [Ilnicki, 2002].

As fossil fuel, peat is not a renewable energy source, although geologically, it is much younger than coal or lignite. Today, peat is treated as a mineral and is subject to the law [Prawo... 2014] under which a license is required in order to mine it.

The use of peat as an energy source is a matter of much controversy. Subject literature is a source of the opinion that peat should be utilized as valuable fertilizer in agriculture and horticulture. In many countries, however (Russia, Canada, Finland, Ireland), peat is mined for energy purposes on mass scale. The results of experiments of burning peat in mixtures with coal and wood biomass (bark, wood chips, waste from forest cleaning) in different proportions, conducted in Finnish thermal power station in Alholmens are presented by Vainikka [2007].

Swedish study presented by Kuczaj [2010] after Olsson [2006] showed large differences in the content of organic compounds (lignin, cellulose, starch, proteins, humic acids) in peat, which distinguishes this material from other fu- 
els, which are much more stable chemically. The use of peat as energy source in Poland is limited, among others, by environment protection laws that determine the exploitation of peat reserves, which are often placed in protected areas [Koprowski, Łachacz 2012]. Peat resources in Poland are estimated at about 1 billion tons p.u. [Szargut, Ziębik 2000]. According to subject literature, moisture content in freshly mined peat can reach $90 \%$, and approx. $25 \%$ when air-dry. Calorific value of lightly dried peat ranges from 10 to $15 \mathrm{MJ} \cdot \mathrm{kg}^{-1}$, and can exceed $20 \mathrm{MJ} \cdot \mathrm{kg}^{-1}$ for dry peat [European... 2007, Tumuluru et al. 2011]. The results obtained for the tested sample were similar.

\section{CONCLUSIONS}

Due to its physical and chemical properties, peat from the tested deposit can be used for agricultural and gardening purposes. These applications are also in accordance with the law. Based on the performed analysis and the comparison of test results with the parameters of other fuels, it can be concluded that the peat mined from the tested deposit can be used as energy source after being brought to air-dry humidity state. Its features are similar to lignite. Peat is not classified as biomass and should be, therefore, treated as nonrenewable fuel. Current Polish regulations limit the use of peat for energy purposes.

\section{REFERENCES}

1. Brandyk T., Gotkiewicz J. Łachacz A. 2008. Zasady racjonalnego wykorzystania torfowisk w rolnictwie. Postępy Nauk Rolniczych 1, 15-26.

2. Dembek W., Piórkowski H., Rycharski M. 2000. Mokradła na tle regionalizacji fizycznogeograficznej Polski. Biblioteczka Wiadomości IMUZ, 97.

3. European Biomass Statistic. AEBIOM, Brussels, Belgium 2007.

4. Ilnicki P. 2002. Torfowiska i torf. Wyd. AR Poznań.

5. Koprowski J., Łachacz A. 2012. Potorfia w krajobrazie rolniczym Pojezierza Dobrzyńskiego.
Współczesne Problemy Kształtowania i Ochrony Środowiska, Monografie ,Wybrane problemy ochrony mokradel”, 3p, 91-110.

6. Kuczaj A. 2010. Emisja związków organicznych przy spalaniu biomasy. Budownictwo i Inżynieria Środowiska, 1, 205-214.

7. Kwiatkowska-Malina J. 2011. Analiza struktury substancji humusowych gleb po wprowadzeniu węgla brunatnego na podstawie widm fluorescencyjnych. Inżynieria i Ochrona Środowiska, 14, 3, 197-208.

8. Oleszczuk R., Regina K., Szajdak L., Höper H., Maryganova V. 2008. Impact of agricultural utilization of peat soils on the greenhouse gas balance. Peatlands and Climate Change. M. Strack (Ed.), International Peat Society, Jyväskylä, Finlandia, 70-97.

9. Okruszko H. 1991. Zasady nawożenia gleb torfowych. Biblioteczka Wiadomości IMUZ, 77, 87-103.

10. Prawo geologiczne i górnicze. Dz.U. 2014 poz. 613.

11. Szafran R. 1997. Podstawy procesów energetycznych. Oficyna Wydawnicza Politechniki Wrocławskiej, Wrocław.

12. Szargut J., Ziębik A. 2000. Podstawy energetyki cieplnej. PWN. Warszawa.

13. Szymanowski M. 1993. Podstawowe właściwości fizyczno-wodne i retencyjne oraz ich zależności od gęstości objętościowej różnych utworów słabo zamulonych (niskopopielnych). Wiadomości IMUZ $17,3,153-174$.

14. Tumuluru J. S., Sokhansanj S., Wright C. T., Boardman R. D., Yancey N. A. 2011. A Review on Biomass Classification and Composition, CoFiring Issues and Pretreatment Methods. ASABE Annual International Meeting.

15. World Energy Council. 2013, www.worldenergy. com

16. Wróbel S. Sienkiewicz-Cholewa U. 2009. Współdziałanie dodatków torfu i wapnowania w uprawie rzepaku ozimego na glebie zanieczyszczonej. Zeszyty Problemowe Postępów Nauk Rolniczych, 538, 373-381.

17. Vainikka P. 2007. Wielopaliwowa elektrociepłownia Alholmens w Zakładach Celulozowo-Papierniczych w Pietrasaari. [W:] Współspalanie biomasy i paliw alternatywnych w energetyce, red. Ściążko M., Zuwała J., Pronobis M., IChPW, Politechnika Śląska, Zabrze.

Pracę dofinansowano ze środków Wojewódzkiego Funduszu Ochrony Środowiska i Gospodarki Wodnej w Lublinie. 